\title{
PERGESERAN SOSIAL BUDAYA MASYARAKAT SUNGAI : SEBUAH PEMBACAAN SOSIOLOGI SASTRA TERHADAP CERITA PENDEK “JUKUNG” KARYA ZULFAISAL PUTERA
}

\author{
Social Cultural Shift of Rider-Side Communities : A Reading of Sociology of Literature on \\ The Short Story “Zukung” by Zulfaisal Putera
}

\author{
Titik Wijanarti \\ Balai Bahasa Kalimantan Selatan \\ Jalan Jenderal Ahmad Yani KM 32,2 Loktabat Banjarbaru Kalimantan Selatan \\ Pos-el titikwijanartibjbr@gmail.com
}

(Naskah Diterima Tanggal 18 September 2019_-Direvisi Tanggal 11 Februari 2020_-Disetujui Tanggal 24

Februari 2020)

\begin{abstract}
Abstrak
Sungai merupakan salah satu bagian penting yang begitu lekat dalam kehidupan masyarakat Banjar Kalimantan Selatan dari waktu ke waktu. Penelitian ini menganalisis sebuah karya sastra yang juga membicarakan kehidupan masyarakat Banjar terkait dengan kehidupan sungai yaitu cerita pendek berjudul "Jukung" karya Zulfaisal Putera. Cerita pendek tersebut menyajikan sebuah konflik keluarga antara tokoh Anang dengan ibunya yang bersumber dari perbedaan pandangan terhadap kehidupan terkait dengan sungai. Masalah itulah yang diuraikan dan dianalisis secara sosiologis dalam penelitian ini. Sesuai dengan rumusan masalah tersebut, penelitian ini bertujuan mendeskripsikan makna sungai secara sosiologis bagi masyarakat Banjar khususnya dalam konstruksi sosial masyarakat terkait dengan pergeseran nilai-nilai dalam masyarakat terkait modernitas dan globalisasi. Penelitian ini memanfaatkan teori sosiologi sastra dengan fokus pembahasan pada keterkaitan antara realitas sosial masyarakat dengan realitas sosial dalam karya sastra. Metode yang digunakan adalah metode deskriptif kualitatif disertai analisi isi. Hasil analisis sosiologi sastra menunjukkan bahwa cerita pendek "Jukung" menggambarkan adanya pergeseran sosial budaya masyarakat Banjar sebagai akibat modernitas.
\end{abstract}

Kata Kunci : cerita pendek, Banjar, sosiologi sastra

\begin{abstract}
The river is one important part that is so attached to the life of the Banjar people of South Kalimantan from time to time. This study analyzes a literary work that also discusses the life of the Banjar community related to river life, namely a short story titled "Jukung" by Zulfaisal Putera. The short story presents a family conflict between Anang and his mother, which originated from differences in views on life related to rivers. That problem is described and analyzed sociologically in this study. In accordance with the formulation of the problem, this study aims to describe the meaning of the river sociologically for the Banjar community, especially in the social construction of the community associated with shifting values in society related to modernity and globalization. This research utilizes the theory of sociology of literature with a focus on the relationship between the social reality of society with social reality in literary works. The method used is a qualitative descriptive method with content analysis. The results of the analysis of literary sociology show that the short story "Jukung" illustrates the socio-cultural shift of the Banjar communities as a result of modernity.
\end{abstract}

Keywords: short stories, Banjar, Sociology of literature. 


\section{PENDAHULUAN}

Sungai bagi masyarakat Kalimantan, khususnya masyarakat Banjar Kalimantan Selatan menduduki posisi yang penting dalam kehidupan. Wilayah Kalimantan Selatan (Ideham et al., 2015) secara geografis banyak dialiri sungai besar maupun kecil. Umumnya sungai-sungai di wilayah Kalimantan Selatan berpangkal di Pegunungan Meratus dan bermuara di Laut Jawa atau Selat Makasar. Banyak istilah yang dipakai utuk menamai aliran sungai karena disesuaikan dengan jenis alirannya, antara lain : batang banyu, hantasan atau antasan, anjir, saka, handil, rai, dan sebagainya. Sungai terbesar adalah Sungai Barito dengan anak sungainya yaitu Sungai Bahan dan Sungai Negara yang merupakan sambungan Sungai Bahan ke arah pedalaman (hlm.7-8). Sungai bagi masyarakat Banjar tidak hanya bermakna sebagai sumber air tetapi juga sebagai orientasi hidup dan identitas diri (Afdholy, 2017). Hal itu karena banyak kegiatan sehari-hari masyarakat dilakukan di sungai (hlm.34).

Secara sosial, sungai merupakan salah satu bagian penting yang begitu lekat dalam kehidupan masyarakat Banjar dari waktu ke waktu. Banyak peristiwa sosial masyarakat yang terjadi di atas sungai. Tidak hanya berkaitan dengan aktivitas perekonomian tetapi banyak peristiwa sosial lainnya seperti terbangunnya rasa simpati, empati, solidaritas, dan juga kemandirian masyarakat yang terbangun dari kehidupan sungai. Wijanarti( 2016) menyatakan bahwa sebagai tempat bertemunya anggota masyarakat, sungai bagi masyarakat Banjar mempunyai peran dalam membentuk kebudayaan dan peradaban masyarakat (hlm.498). Sementara itu, (Mentayani, 2019) mengutip pendapat Saleh yang menyatakan bahwa sungai di wilayah Kalimantan Selatan merupakan faktor utama dalam lalu lintas pengangkutan, urat nadi ekonomi, jalur penyebaran kebudayaan, wilayah kekuasaan keraton, dan juga wilayah kekuasaan penjajahan di abad ke17 sampai abad ke-19 (hlm.499). Kajian historis juga menunjukkan bahwa jalur sungai merupakan jalur penting perdagangan masyarakat Banjar pada pertengahan abad XIX (Endang, 2011).

Seiring dengan perubahan zaman, kehidupan masyarakat Banjar secara sosial budaya juga ikut mengalami perubahan termasuk dalam kaitannya dengan kehidupan sungai. Rochgiyanti( 2011) mengemukakan bahwa pertambahan penduduk dan pembangunan perumahan di wilayah darat mengakibatkan berkurangnya aktivitas masyarakat di atas sungai (hlm.55). sependapat dengan hal tersebut, Abidin (2016) menyatakan bahwa sebelum infrastruktur jalan dibangun, masyarakat Banjarmasin sangat bergantung pada sungai sebagai sarana transportasi utama. Kondisi tersebut tersebut berubah sejak akhir tahun 1960 . Transportasi sungai mulai ditinggalkan masyarakat Banjar sebagai dampak gencarnya pembangunan jalan darat. Pembangunan jalan darat kemudian juga berdampak pada pesatnya pertumbuhan kendaraan bermotor. Sejak tahun 1970 pemanfaatan sungai di Kota Banjarmasin mengalami penurunan. Sungai di Banjarmasin pada masa sekarang hanya digunakan sebagai alat transportasi lokal. Transportasi antarprovinsi yang melalui jalur sungai pada masa sekarang dikhususkan hanya pada angkutan barang (hlm.23).

Pergeseran sosial budaya masyarakat terkait dengan kehidupan sungai tersebut juga dapat dilihat dalam beberapa karya sastra. Karya sastra sebagai bagian dari kekayaan intelektual masyarakat dalam konteks tertentu mampu merekam, mendokumentasikan, dan mereproduksi kisah kehidupan manusia, termasuk kehidupan masyarakat di atas sungai. Contoh karya sastra yang membicarakan kehidupan sosial masyarakat Banjar di atas sungai antara lain adalah cerita pendek 
"Senja Kuning Sungai Martapura"( 2008) karya Sandi Firly dan puisi "Sungai Martapura" karya Jamal T.Suryanata (Suryanata, 2014.). Cerita pendek "Senja Kuning Sungai Martapura" mengangkat sebuah mitos yang beredar di kalangan masyarakat Banjar yaitu tentang bahaya 'senja kuning'. Mitos 'senja kuning' adalah kepercayaan masyarakat Banjar yang melarang masyarakat berada di luar rumah pada saat senja. Apabila mitos tersebut dilanggar, akan menimbulkan bahaya bagi orang yang melanggarnya. Sementara itu, puisi "Sungai Martapura" berisi kerinduan penyair terhadap nilai dan simbol-simbol romantisme Sungai Martapura yang telah terdegradasi oleh nilai-nilai modernitas. Banyak nilai-nilai romantis masyarakat yang telah hilang sebagai dampak pergeseran sosial budaya masyarakat Banjar dari masyarakat tradisional ke masyarakat modern.

Aktivitas kesastraan di wilayah Kalimantan Selatan terus mengalami pertumbuhan dan perkembangan. Hal tersebut dinyatakan oleh Suryanata ( 2015) bahwa sejak memasuki awal abad ke-21 yang lalu, dinamika sastra di Kalimantan Selatan menunjukkan perkembangan yang sangat menggembirakan. Perkembangan itu bukan hanya terlihat dari tingkat produktivitas penulisannya yang semakin tinggi, melainkan juga tampak pada tradisi penerbitannya yang kian marak dewasa ini. Selain telah dikenal sebagai "lumbung penyair" sejak puluhan tahun silam, kini juga bermunculan cerpenis dan novelis muda berbakat yang boleh dilihat sebagai sebuah fenomena baru dalam tradisi sastra di wilayah Kalimantan Selatan (hlm.ix).

Penelitian ini menganalisis sebuah karya sastra yang juga membicarakan kehidupan masyarakat Banjar terkait dengan kehidupan sungai yaitu cerita pendek berjudul "Jukung". Cerita pendek "Jukung" ditulis oleh Zulfaisal Putera dan diterbitkan bersama beberapa cerita pendek yang lain dalam bentuk antologi berjudul Di Perbatasan Kota Bunga (Putera, 2011).
Cerita pendek tersebut menyajikan sebuah konflik keluarga yang bersumber dari perbedaan pandangan terhadap kehidupan terkait dengan sungai. Hal yang cukup penting untuk dicermati bahwa perbedaan pandangan tersebut terjadi antara tokoh Anang (seorang anak laki laki) dengan tokoh Mama (ibunya) dalam cerita pendek tersebut. Tokoh Anang dalam cerita pendek tersebut dapat dilihat sebagai tokoh cerita yang mewakili kaum laki-laki dan modern. Sementara tokoh Mama dapat dilihat sebagai representasi perempuan Banjar dan mewakili masyarakat Banjar yang tradisional.

Perbedaan pandangan antara tokoh Anang dan tokoh Mama dalam cerita pendek tersebut dapat dilihat sebagai pertentangan antara dua sudut pandang yang berbeda. Tokoh Anang dapat dilihat sebagai masyarakat Banjar yang telah hidup dengan pandangan modern dan tokoh Mama adalah masyarakat Banjar yang hidup dalam pandangan tradisional . Mereka memiliki perbedaan dalam memandang sungai.

Pertentangan antara keduanya menjadi penting dan menarik untuk diuraikan dalam kaitannya dengan konstruksi sosial masyarakat Banjar khususnya pada era globalisasi sekarang ini. Masalah itulah yang akan diuraikan dan dianalisis secara sosiologis dalam penelitian ini. Sesuai dengan rumusan masalah tersebut, penelitian ini bertujuan mendeskripsikan makna sungai secara sosiologis bagi masyarakat Banjar khususnya dalam konstruksi sosial masyarakat terkait dengan pergeseran nilai-nilai dalam masyarakat dari tradisional ke masyarakat modern. Berdasarkan masalah dan tujuan penelitian, pembahasan dalam penelitian ini didasarkan pada konsep sosiologi sastra. Teori sosiologi sastra secara umum dan mendasar didasarkan pada konsep dan pandangan adanya hubungan antara struktur realitas sosial dalam masyarakat dengan struktur realitas sosial di dalam 
karya sastra. Hal tersebut dapat terjadi karena pengarang sebagai pencipta atau produsen karya sastra merupakan bagian dari anggota sebuah kelompok sosial atau masyarakat. Endraswara menyatakan bahwa pada umumnya jarang disadari adanya kesamaan struktur masyarakat dan struktur karya sastra (2013). Homologi struktur masyarakat dan struktur karya sastra seharusnya dipahami sebagai sebuah dialektis. Struktur masyarakat sebagai bagian kemestaan ditata oleh manusia. Begitu pula sastra, ditata secara imajinatif oleh manusia (hlm.21).

Ratna (2003) mengemukakan bahwa tujuan studi sosiologi sastra adalah meningkatkan pemahaman terhadap sastra dalam kaitannya dengan masyarakat, menjelaskan bahwa rekaan tidak berlawanan dengan kenyataan. Karya sastra jelas dikonstruksikan secara imajinatif, tetapi kerangka imajinatifnya tidak bisa dipahami di luar kerangka empirisnya. Karya sastra bukan sematamata sebagai gejala individual, melainkan juga gejala sosial (hlm.11). Lebih lanjut Endraswara(2013) mengemukakan bahwa sastra adalah sebuah dokumen penting tentang zaman. Sebagai dokumen zaman, sastra berusaha mencatat kejadian zaman. Tiap zaman selalu memiliki aneka ragam kepentingan. Studi sosiologi sastra berusaha menangkap dokumen peristiwa yang istimewa di mata sastrawan. Berbagai konteks sosial sering mewarnai setiap zaman yang berbeda (hlm.91).

Kajian-kajian sastra yang berupaya melihat kedekatan antara karya sastra dengan kehidupan sosial budaya masyarakat telah banyak dilakukan dalam penelitian-penelitian sebelumnya. Penelitian tersebut antara lain yang dilakukan oleh Asri (2011), Utomo (2014), Wijanarti ( 2016), dan Yulianto( 2017). Penelitian-penelitian tersebut membuktikan adanya hubungan antara realitas sosial yang terjadi di tengah masyarakat dengan realistas sosial dalam karya sastra. Penelitian yang dilakukan
Asri menunjukkan adanya hubungan yang erat antara realitas dalam kehidupan masyarakat Minangkabau dengan masyarakat yang digambarkan dalam cerita pendek "Si Padang". Sementara itu, penelitian Utomo berhasil menggambarkan bahwa kerusakan alam Kalimantan Timur sebagai dampak industrialisasi terhadap hutan dapat dibaca melalui karya-karya sastrawan Kalimantn Timur baik dalam genre puisi maupun prosa. Wijanarti (2016) melihat adanya fungsi sosial dalam kehidupan sungai bagi masyarakat Banjar yang berhasil digambarkan oleh Jamal $\mathrm{T}$ Suryanata dalam puisi "Sungai Martapura". Sementara itu, Yulianto (2017) menguraikan adanya pergeseran kehidupan masyarakat Kota Banjarmasin dari masyarakat religius menjadi masyarakat yang mulai menunjukkan adanya berbagai macam kerusakan moral sebagai akibat kehidupan modern.

\section{METODE}

Metode yang diterapkan dalam penelitian ini adalah metode analisis isi / analisis konten. Analisis isi (content analysis) menurut Vredenbreght seperti yang dikutip oleh Ratna (2016) berkaitan dengan (isi) komunikasi. Komunikasi itu sendiri dalam hubungan ini paling sedikit melibatkan tiga komponen dengan fungsinya masingmasing,yaitu : a) siapa yang berbicara, b) apa yag dibicarakan, dan c) efek apa yang diakibatkannya. Di antara ketiga komponen tersebut yang terpenting adalah komponen yang kedua yaitu 'apa' isi komunikasi tersebut. Bentuk komunikasi yang dimaksud dapat berupa verbal maupun nonverbal,lisan maupun juga tulisan (hlm.357-358). Berdasarkan pengertian tersebut, cerita pendek "Jukung" dalam penelitian ini ditempatkan sebagai bentuk komunikasi antara pengarang dengan masyarakat pembaca dan fokus utama analisis dalam penelitian ini adalah 'isi' dari cerita pendek tersebut. 
Sementara itu, Endraswara (2011) juga mengemukakan bahwa analisis konten perlu digunakan apabila peneliti ingin mengungkap, memahami, dan menangkap pesan karya sastra. Analisis konten adalah sebuah strategi untuk menangkap pesan karya sastra. Tujuan analisis konten adalah membuat inferensi. Inferensi diperoleh melalui identifikasi dan penafsiran. Inferensi juga berdasarkan konteks yang melingkupi karya sastra. Prosedur penelitian analisis konten adalah : (1) pengadaan data penelitian yang meliputi tiga tahap yaitu : penentuan unit analisis, penentuan sampel, dan perekaman atau pencatatan data, dan (2) proses inferensi dan analisis (hlm.160-163).

Berdasarkan prosedur analisis konten seperti yang diungkapkan oleh Endraswara tersebut, metode kerja dalam penelitian ini dilakukan dalam tahap-tahap berikut.

1. Tahap Pengadaan data penelitian. Tahap pengadaan data penelitian ini terbagai dalam tiga langkah : pertama, penentuan unit analisis yaitu dengan melakukan pembacaan terhadap berbagai karya sastra yang mengangkat topik kehidupan masyaraat Banjar di atas sungai. Langkah kedua adalah penentuan sampel penelitian. Setelah dilakukan pembacaan terhadap berbagai karya sastra tersebut, cerita pendek "Jukung" karya Zulfaisal Putera dipilih sebagai sampel penelitian ini. Cerita pendek "Jukung" dipilih dalam penelitia ini karena didasarkan pada alasan bahwa cerita pendek tersebut menggambarkan kehidupan sungai masyarakat Banjar sekaligus menghadirkan pertentangan sebagai akibat adanya pergeseran sosial budaya masyarakat. Langkah ketiga adalah pencatatan data. Pencatatan data yang dimaksud adalah dengan mencatat data-data sosiologis yang ditemukan dalam cerita pendek tersebut.

2. Proses inferensi dan analisis merupakan proses analisis data penelitian berdasarkan kerangka teori yang telah ditetapkan yaitu teori sosiologi sastra.

\section{PEMBAHASAN \\ Sinopsis Cerita Pendek “Jukung” Karya Zulfaisal Putera}

Cerita pendek "Jukung" menampilkan tokoh Anang, seorang laki-laki muda yang telah bekerja pada sebuah perusahaan swasta dan telah memiliki dua orang anak. Anang tinggal di sebuah rumah di tepian Sungai Barito,dekat dengan lanting (lanting : rumah tinggal dari kayu yang diapungkan di atas sungai) ibunya (tokoh Mama). Konflik cerita dimulai ketika tokoh Mama kebingunangan mencari kayuh untuk jukungnya (jukung : perahu kecil tidak bermesin). Tokoh Mama merasa sangat sedih ketika tak kunjung menemukan kayuh tersebut. Itu berarti ia tidak akan bisa mengayuh jukung untuk berjualan aneka sayur mayur pada keesokan harinya. Kayuh tersebut sebenarnya disembunyikan oleh Anang karena ia tak menginginkan ibunya berjualan di Sungai Barito dengan alasan ibunya telah tua.

Sementara itu, tokoh Mama selalu mencari cara agar dapat terus berjualan di Sungai Barito. Baginya, mengayuh jukung untuk berjualan telah menjadi bagian dari kehidupannya. Ketika kayuh tidak ditemukan, Mama tetap mengayuh jukung menggunakan potongan papan lantai jukung yang sengaja dilepas dan digunakan sebagai pengganti kayuh. Anang dan Mama beberapa kali berdebat sengit terkait kegiatan mamanya yang masih berjualan menggunakan jukung setiap pagi. Anang melihat ibunya telah cukup tua untuk menjalani pekerjaan tersebut. Anang juga merasa telah memiliki penghasilan yang cukup dengan bekerja pada sebuah 
perusahaan. Ia ingin ibunya beristirahat di rumah.

Sementara bagi Mama, mengayuh jukung dan berjualan merupakan bagian dari nadi kehidupannya. Ia merasa memiliki banyak ikatan emosional dengan jukung dan juga pekerjaannya. Mama tidak ingin dihalangi oleh siapa pun. Baginya, tetap berjualan dengan mengayuh jukung merupakan bagian dari uasahanya untuk menjaga amanah almarhum suaminya. Ia tetap pada pendiriannya, tetap berjualan dan mengayuh jukung setiap pagi. Hingga pada suatu pagi Anang merasa terkejut mendapati ibunya telah tidak ada di lanting bersama jukungnya. Ia segera bergegas mencari ibunya. Ia merasa gelisah dan khawatir karena tanpa sepengetahuan ibunya ia telah melubangi lantai jukung sebagai cara untuk mengahalangi ibunya mengayuh jukung dan berjualan. Pencarian Anang tidak membuahkan hasil, ia hanya menemukan jukung ibunya yang karam di tengah Sungai Barito.

\section{Tinjauan Sosiologi sastra Cerita Pendek “Jukung” Karya Zulfaisal Putera}

Sungai bagi masyarakat Banjar, secara fisik merupakan salah satu tempat tinggal yang memberikan kenyamanan dan keindahan. Banyak kegiatan khas masyarakat yang dapat mereka lakukan di atas sungai. Sungai seolah-olah mampu memberikan semua yang dibutuhkan masyarakat untuk aktivitas kehidupan sehari-hari. Berikut kutipan cerita pendek "Jukung" yang menggambarkan kondisi tersebut.

(1) Beginilah rutinitas setiap pagi tiba di sepanjang sungai itu. Para penghuni tepian memenuhi batang-batang dan lanting untuk melakukan kegiatan bersih-bersih. Batang-batang itu saling bersisihan dengan jarak dua tiga buah rumah dan saling berseberangan dengan dipisahkan sungai yang membelah. Di atasnyalah semua ativitas pagi warga dilakukan. Ada yang mandi, berenang, mencuci pakaian, buang hajat di jamban, bahkan sekadar duduk sambil menghirup udara segar (Putera, 2011,hlm.59-60).

Selain secara fisik sungai difungsikan sebagai tempat permukiman, bagi masyarakat Banjar sungai juga menjadi tempat sosialisasi antarwarga. Banyak warga yang bisa saling bertegur sapa satu sama lain ketika mereka melakukan aktivitas di atas sungai. Salah satunya adalah melalui aktivitas perdagangan. Melalui transaksi jual beli antara penjual dan pembeli baik berupa transaksi barang maupun jasa, mereka dapat saling bersosialisasi satu sama lain. Sungai secara sosial mampu menjadi salah satu sarana untuk menjaga integritas sosial di kalangan masyarakat Banjar.

(2) Pagi datang lagi. Rutinitas pagi mulai lagi. Setiap orang mulai mengisi tepi-tepi sungai, di batangbatang, atau pelataran lanting. Mereka mandi, mencuci, atau buang air, sambil bercengkrama, berdendang, atau sekadar berguman. Semua gembira. Semua suka cita. Setiap pagi adalah awal hari yang memiliki harapan (Putera, 2011,hlm.71).

\section{Makna Sungai bagi Masyarakat Banjar Tradisional dalam Cerita Pendek}

Representasi masyarakat Banjar tradisional dalam cerita pendek tersebut dapat dilihat pada sikap tokoh Mama dalam menempatkan sungai dalam kehidupannya. Sungai bagi tokoh Mama tidak hanya memiliki makna geografis sebagai bagian dari tempat tinggal tetapi juga memiliki makna historis, sosiologis, ekonomis, dan romanitis. Secara historis, kehidupan di atas sungai telah memberikan banyak kenangan sepanjang perjalanan hidup tokoh Mama. Cerita pendek tersebut menggambarkan banyak hal yang telah dijalani tokoh Mama bersama keluarga dan masyarakat lingkungannya di atas Sungai Barito. Kutipan berikut memperlihatkan ikatan emosional yang 
Wijanarti: Pergeseran Sosial Budaya ...

begitu kuat antara Mama dengan kehidupan sungai.

(3) "Maafkan ulun, Bang!"

Suaranya datar. Samar terdengar.

"Maafkan ulun tak bisa menjaga amanat Pian!"

"Ulun tahu, Pian pasti kecewa mendengarnya."

Suara perempuan itu makin menghiba. Matanya dingin menatap gundukan tanah di depannya.

"Bang, Pian masih ingat dengan jukung kita? Jukung yang sering kita gunakan berdua ke mana-mana? Tanya perempuan itu seolah sedang berdialog dengan seseorang.

"Jukung itu memberi hidup bagi kita, Bang! Dengan jukung itu Pian bisa mencari nafkah untuk kelangsungan hidup kita dan di jukung itu pula kita menjalani lebih banyak waktu hidup".

Dan ketika Anang, anak kita lahir, di jukung itulah waktu kita habiskan untuk membesarkannya!"

"Yang paling kuingat, di jukung ini pula Abang meninggalkan kami!"

Ketika itu, Abang sesak nafas. Aku pikir Abang masuk angina biasa. Namun, ternyata sesak nafas itu yang mengantarkan Abang pergi..." (Putera, 2011,hlm.75).

Kutipan tersebut memperlihatkan bahwa kehidupan di atas Sungai Barito yang diwakili oleh jukung merupakan kehidupan yang penuh makna bagi tokoh Mama. Jukung bagi Mama bukan hanya sebagai alat untuk mencari penghasilan melainkan menjadi simbol kehidupannya. Ketika jukung itu karam, ia merasa sangat sedih karena ia merasa telah gagal dalam mempertahankan kehidupannya. Jukung itu juga menjadi simbol keromantisan antara Mama dengan almarhum suaminya. Kedekatan tokoh Mama dengan sungai juga dapat dilihat dalam kutipan berikut.

(4) "Aku jangan dilarang untuk menjalani apa yang aku sukai. Aku mengayuh jukung dan mengaluri sungai dari kampung ke kampung bukanlah sekadar mencari rejeki.
Aku mengayuh jukung karena memang aku mencintai pekerjaan ini. Sejak Anang suamimu masih dalam kandungan, aku sudah mengaluri sungai-sungai di kota ini. Jukung ini adalah jiwaku. Sungai ini adalah ruhku. Jadi jangan dipisah aku dengan jukung dan sungai ini. Apa pun cara kalian agar aku tak menarik jukung, tidak akan mampu menghalangiku

(Putera, 2011,hlm.68-69).

Sungai bagi masyarakat Banjar juga merupakan pusat perekonomian yang penting. Sungai Barito dalam cerita pendek tersebut digambarkan sebagai pusat perekonomian yang ramai khususnya di pagi hari. Situasi tersebut dapat dilihat dalam kutipan cerita pendek berikut ini.

(5)Seperti subuh ini, seperti saat ini, perempuan tua itu seharusnya sudah menuju tengah Sungai Barito, bergabung bersama puluhan jukung yang lain. Memusat dan menambat pada jukung tiung atau klotok-klotok besar. Memilih, menawar, dan memindahkan barang-barang kebutuhan hidup sehari-hari ke jukung masing-masing untuk dijual kembali. Dan perempuan tua itu biasanya membeli sayur mayur dan ikan dari perahu besar itu. Selanjutnya dia menuju sungaisungai kecil untuk menjajakan kembali sayur dan ikan itu (Putera, 2011,hlm.58).

Gairah aktivitas perekonomian seperti yang terlihat dalam kutipan tersebut memperlihatkan bahwa sungai menjadi tempat transaksi masyarakat yang penting dan menjanjikan. Sebagai pusat transaksi, sungai tampak 'ramah' kepada perempuan. Ia bukan hanya tempat yang didominasi oleh pedagang laki-laki melainkan juga pedagang perempuan. Dalam konteks ini dapat dilihat bahwa secara sosiologis, sungai merupakan salah satu tempat yang menawarkan kehidupan dan kemandirian kepada kaum perempuan Banjar. Tokoh Mama yang digambarkan telah berusia 60 
tahun masih mampu dan merasa aman menjadi bagian dari komunitas perdagangan di Sungai Barito. Fakta tersebut memperlihatkan bahwa sungai memiliki peran yang penting dalam membentuk konstruksi sosial budaya masyarakat Banjar.

Tokoh Mama dalam cerita pendek "Jukung" digambarkan memiliki kemandirian dalam menjalani kehidupannya di Sungai Barito. Kemandirian tersebut tidak hanya menyangkut masalah fisik yang digambarkan dengan kemampuannya mengayuh jukung tetapi juga secara mental. Mama digambarkan terbiasa mengatasi persoalannya sendiri meskipun ia tinggal tidak jauh dengan anaknya.

(6) Perempuan tua itu tak ingin membangunkan orang rumah hanya sekadar menanyakan itu. Dia tahu, anak, menantu, dan dua cucunya pastilah masih tertidur lelap. Apalagi mereka tinggal di rumah sendiri yang berdiri di tepi sungai bersisihan dengan lantingnya. Jika perempuan tua itu ingin, dia tinggal meniti kayu lebar titian penghubung ke pelataran rumah dan mengetuk pintunya. Namun, dia tidak melakukannya. Perempuan tua itu terbiasa mengatasi masalahnya sendiri (Putera, 2011,hlm.58).

\section{Makna Sungai bagi Masyarakat Banjar Modern dalam Cerita Pendek}

Pandangan masyarakat Banjar modern dalam cerita pendek "Jukung" dapat dicermati melalui sikap dan pandangan yang ditunjukkan oleh tokoh Anang. Hal tersebut terutama dapat dilihat pada sikap Anang ketika menghadapi Mama yang masih ingin berjualan dengan mengayuh jukung di Sungai Barito. Anang beberapa kali terlibat perdebatan yang cukup sengit dengan ibunya karena tidak setuju dengan aktivitas ibunya di Sungai Barito. Salah satu perdebatan Anang dengan tokoh Mama dapat dilihat dalam kutipan cerita pendek berikut.
(7) "Mama tidak usah jualan keliling pakai jukung lagi!",

"Mama kan sudah tua. Sudah enam puluh tahun. Sudah saatnya pian di rumah saja."

"Mama tidak bisa, Nang!" sahut Ibu ketika itu.

Mama kan perlu cari nafkah buat hidup," kata Ibu melanjutkan.

"Mama cari nafkah buat siapa?"

"Ya,buatku sendiri. Buat cucu-cucuku."

"Mama tidak usah cari uang lagi. Tidak usah ada alasan buat cucu segala!" tangkis suamiku.

"Biar ulun saja yang cari nafkah,Ma! Gaji ulun di perusahaan cukup saja untuk membiayai seisi rumah ini. Untuk pian juga!"

"Sombong!" sahut Mama ketus, "Ikam itu sejak dalam perut sampai besar aku beri makan dari jualan keliling pakai jukung!"

(Putera, 2011,hlm.63).

Kutipan tersebut memperlihatkan sikap dan pandangan Anang yang berbeda dengan ibunya. Bagi Anang, sungai bukanlah tempat yang aman bagi ibunya yang telah tua. Ia mengkhawatirkan ibunya jika masih terus berjualan di Sungai Barito. Secara ekonomis, Anang telah merasa mampu untuk menopang kehidupan ibunya. Hal berbeda tampak pada tokoh Mama, ia memandang bahwa berjualan di sungai bukan merupakan persoalan baginya walaupun ia telah tua. Penolakannya terhadap tawaran Anang yang ingin menopang hidupnya, terdorong oleh sikap kemandirian yang telah tertanam kuat dalam dirinya. Kutipan tersebut sekaligus menyiratkan dua pandangan yang berbeda tentang sungai.

Bagi Mama sebagai representasi kaum tradisional, sungai adalah tempat kehidupan yang aman, menyenangkan, dan tetap menjanjikan. Sama sekali tidak ada ketakutan dan kekhawatiran dalam menghadapi persaingan kehidupan di atas sungai. Sebaliknya, bagi Mama sungai justru akan selalu menjanjikan harapan dan rasa optimis. Sedangkan bagi Anang yang 
dapat dilihat sebagai representasi manusia modern, sungai sudah tidak ramah lagi, khususnya bagi orang yang telah lanjut usia. Bagi Anang, sungai bukan lagi tempat yang menguntungkan secara ekonomi, itu tampak dari sikapnya yang lebih membanggakan gajinya di perusahaan. Peran ekonomi menurut Anang harus dipegang oleh anak muda, hal itu terkait dengan korelasi antara usia produktif dengan hasil material yang diperoleh. Sementara bagi Mama yang masih tradisional, peran ekonomi tidak terbatas pada usia. Keuntungan tidak harus selalu diukur kepada segala yang bersifat material. Keuntungan bagi Mama bisa saja berupa kebahagiaan, kebebasan, dan kemandirian.

\section{Hubungan Makna Sungai dalam Cerita Pendek dengan Realitas Sosial Masyarakat Banjar Masa kini.}

Secara historis, kehidupan masyarakat Banjar sebenarnya memang tidak dapat dilepaskan dengan sungai. Hal itu dapat dilihat dengan banyaknya istilah dan hasil teknologi yang mampu diciptakan masyarakat Banjar terkait sungai. Ideham (Ideham et al., 2015) mengemukakan berbagai jenis jukung yang dihasilkan oleh masyarakat Banjar tradisional. Jukung menurut proses pembuatannya ada tiga jenis yaitu jukung sudur, jukung patai, dan jukung batambit. Berdasarkan fungsinya, jukung ada berbagai macam yaitu : jukung paramuan, jukung palambakan, jukung pambarasan, jukung gumbili, jukung pamasiran,jukung beca banyu, jukung getek, jukung palanjaan, jukung rombong, perahu tambangan, jukung undaan, dan jukung tiung (hlm.293-298).

Sejak masa Orde Baru, pembangunan yang terkait dengan fisik seperti infrastruktur jalan terus digalakkan, termasuk di Kalimantan Selatan. Pembangunan tersebut terus berlangsung hingga saat ini dan tentu memiliki dampak tidak hanya dampak fisik tetapi juga sosial budaya. Terbukanya akses jalan raya yang menghubungkan antarwilayah telah meciptakan kantong-kantng perekonomian baru yang tidak lagi berpusat di sungai. Pasar-pasar sebagai pusat transaksi masyarakat Banjar, kini tidak harus terjadi di atas sungai tetapi bisa saja di darat yang terus bertumbuh dan berkembang dengan pesat. Perekonomian di darat terus menggeliat, sementara sungai mengalami stagnasi. Pemertahanan perekonomian sungai di masa kini lebih berorientasi pada pasar pariwisata.

Cerita pendek "Jukung" seperti yang telah diuaraikan dalam penelitian ini sebenarnya tidak menyajikan persoalan yang sederhana tentang konflik antara ibu dan anak. Ada hal lain yang lebih besar yang disampaikan cerita pendek tersebut yaitu pertentangan antara tradisional dan modernitas. Perahu kayu yang bernama 'jukung' dalam cerita pendek tersebut sesungguhnya merupakan simbol tradisionalitas yang terus diperdebatkan dari awal hingga akhir cerita. Kebahagiaan tokoh Mama yang tidak semuanya bisa diukur secara material harus menyerah kalah ketika digambarkan jukung tersebut sengaja dikondisikan untuk tenggelam di tengah Sungai Barito. Kesedihan dan kepiluan hati Mama ketika jukungnya telah tenggelam tidak dapat disamakan dengan kesedihan seorang manusia yang sedang kehilangan sebuah benda. Karamnya jukung tersebut bisa dibaca sebagai tenggelamnya nilai-nilai tradisionalitas yang penuh dengan sejarah,kearifan, dan romantisme.

\section{PENUTUP}

Berdasarkan analisis sosiologi sastra terhadap cerita pendek berjudul "Jukung" karya Zulfaisal Putera dapat disimpulkan bahwa cerita pendek tersebut menyajikan konflik antara tokoh Anang dan Mama tentang aktivitas Mama. Sumber konflik adalah keinginan Mama untuk tetap berjualan di Sungai Barito dengan menggunakan jukung dalam usianya yang 
telah menua. Konflik tersebut bukanlah konflik yang sederhana antara ibu dan anak. Ada masalah lain yang tersirat dalam konflik tersebut. Masalah tersebut adalah terdesaknya kehidupan perekonomian sungai sebagai ciri kehidupan masyarakat tradisional Banjar oleh kehidupan modern yang penuh ditandai dengan symbol-simbol materialitas. Karya sastra dalam kondisi

\section{DAFTAR PUSTAKA}

Abidin, Z. (2016). Studi Revitalisasi Angkutan Sungai Sebagai Moda Transportasi Perkotaan di Kota Banjarmasin. Agregat, 1(1), 23-32.

Afdholy, A. R. (2017). Tipomorfologi Permukiman Tepian Sungai Martapura Kota Banjarmasin. Local Wisdom: Jurnal Ilmiah Kajian Kearifan Lokal, 9(1), 33-50. https://doi.org/10.26905/lw.v9i1.1865

Asri, Y. (2011). Analisis Sosiologis Cerpen "Si Padang" karya Harris Effendi Thahar. Humaniora, 23(3), 245-255.

Endang, S. (2011). Peranan Jaringan Sungai sebagai Jalur Perdagangan di Kalimantan Selatan pada Paroh Abad XIX. CITRA LEKHA, XV(1), 1-8.

Endraswara, S. (2011). Metodologi Penelitian Sastra. Yogyakarta: Penerbit Ombak.

Endraswara, S. (2013). Sosiologi Ssatra: Studi,Teori, dan Interpretasi. Yogyakarta: Penerbit Ombak.

Ideham et al. (2015). Urang Banjar dan Kebudayaannya (Banjar people and their culture). Retrieved from www.penerbitombak.com

Mentayani, I. (2019). Identitas dan Eksistensi Permukiman Tepi Sungai di Bnajarmasin. Prossiding Seminar Nasional Lingkungan Lahan Basah Vol.4 No.3, 497-502.

Putera, Z. (2011). Jukung. In Hajriansyah (Ed.), Di Perbatasan Kota Bunga. Banjarmasin: Tahura Media.

Ratna, N. . (2003). Paradigma Sosiologi tertentu mampu menyampaikan realitas sosial dalam kerangka imajinatif namun tetap memiliki keterkaitan dengan realitas yang sesungguhnya. Cerita pendek "Jukung" telah membuktikan hal tersebut. Dalam kemasan bahasa yang sederhana dan penuh diwarnai dengan warna-warna local khas Banjar, cerita pendek "Jukung" telah berhasil menjadi cerita pendek yang menarik dan sarat dengan makna.

Sastra. Yogyakarta: Pustaka Pelajar.

Ratna, N. K. (2016). Metodologi Penelitian Kjaian Budaya dan Ilmu Sosial Humaniora pada Umumnya. Yogyakarta.

Rochgiyanti. (2011). Fungsi Sungai Bagi Masyarakat di Tepian Sungai Kuin Kota Banjarmasin. Jurnal Komunitas, 3(1), 51-59.

Sandi Firly. (2008). Senja Kuning Martapura. In Perempuan yang Memburu Hujan (pp. 1-5).

Suryanata, J. (n.d.-a). Menyimak Obrolan Kritis Sumasno Hadi. In S. Hadi (Ed.), Dialektika Seribu Sungai. banjarmasin: Lambung Mangkurat University Press.

Suryanata, J. (n.d.-b). Sungai Martapura. In Kitab Cinta. Banjarbaru: Scripta Cendekia.

Utomo, I. B. (2014). Kerusakan Alam Kalimantan Timur Di Mata Ssatrawan Lokal. Atavisme, 17(1), 17-28.

Wijanarti, T. (2016). Makna Sungai dalam Puisi Sungai Martapura Karya Jamal T.Suryanata. Mlangun, 12(2), 497575.

Wijanarti, Titik, Bahasa, B., Selatan, K., \& Selatan, B. K. (2016). KARYA JAMAL T. SURYANATA Meaning of River in Poetry " Sungai Martapura " by Jamal T. Suryanata. 497-505.

Yulianto, A. (2017). Strukturalisme Genetik Cerpen Hitam Putih Kotaku Karya Rismiyana. Mlangun, 14(2), 713-725. 